\title{
Assessing Groundwater Availability in the High Plains Aquifer in Parts of Colorado, Kansas, Nebraska, New Mexico, Oklahoma, South Dakota, Texas, and Wyoming
}

\section{Assessing Ground water Availability on a National Scale}

The U.S. Geological Survey's Groundwater Resources Program is conducting an assessment of groundwater availability to gain a clearer understanding of the status of the Nation's groundwater resources and the natural and human factors that can affect those resources. The goals of this national effort are to define the current status and improve understanding of the Nation's groundwater resources, to better estimate availability and suitability of those resources for use in the future, and to provide tools to estimate the future availability of groundwater for its various uses. Assessments will be completed for regional aquifer systems across the Nation to help characterize how much water we have, where groundwater resources are most stressed, how groundwater availability is changing, and where groundwater resources are most available for future use (Reilly and others, 2008).

The concept of "groundwater availability" means more than just how much water is usable from the aquifer and how much more is left in the aquifer. Groundwater availability depends on factors such as geology of the aquifer, environmental factors, quality of the water, regulations and water law, economics of pumping the water to the surface, and possibility that groundwater withdrawals can adversely affect surface water. The objectives of the High Plains groundwater-availability study are to (1) more fully understand regional and temporal trends in the overall water budget, including natural inflows, outflows, storage, and human uses (such as irrigation), and (2) identify the natural and human processes that control this budget. Development of tools such as groundwater models can help gain an understanding of the hydrologic system, allowing forecasts to be made about response of the system to natural and human stresses.

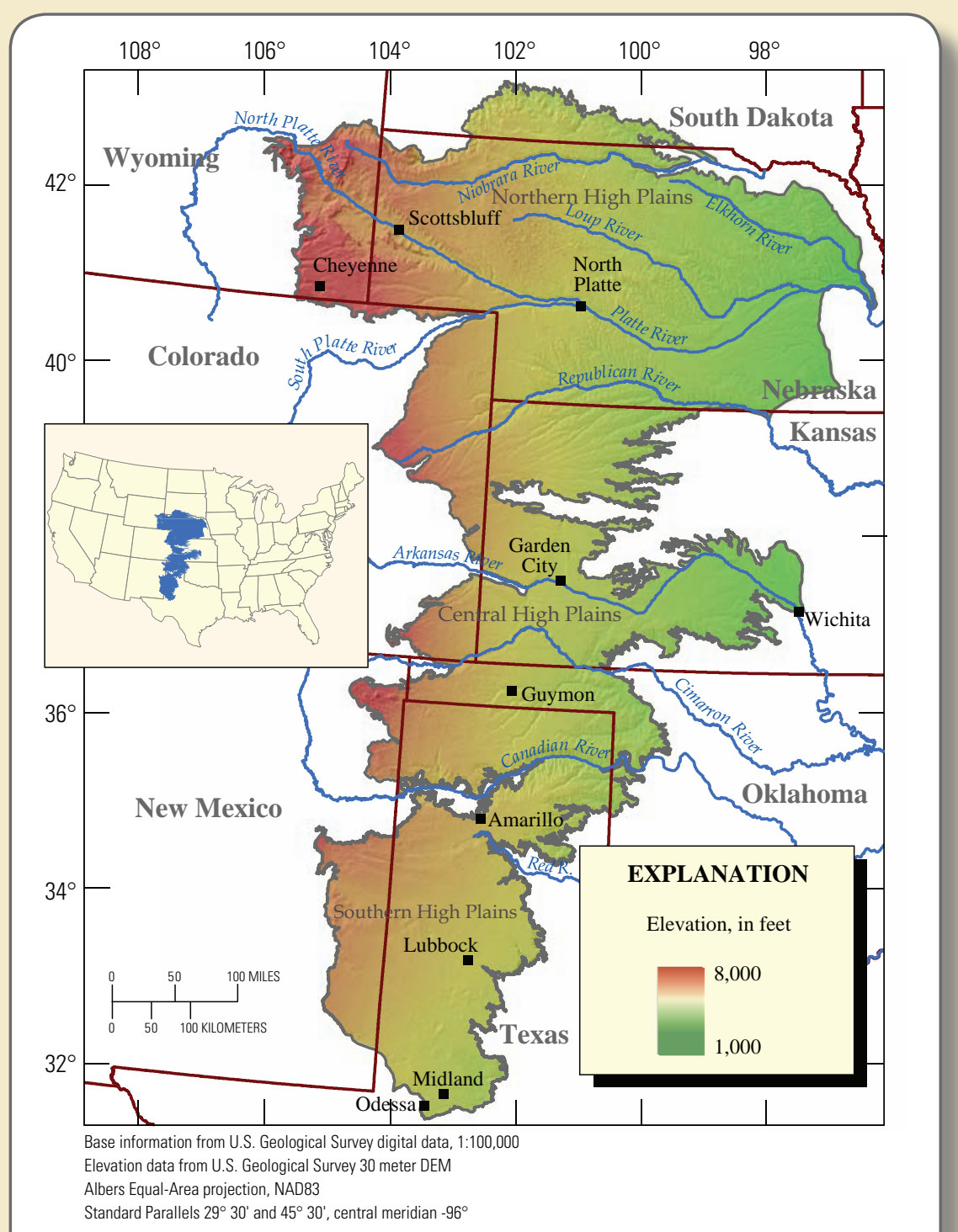

Figure 1. Location of the High Plains aquifer within the central United States. 


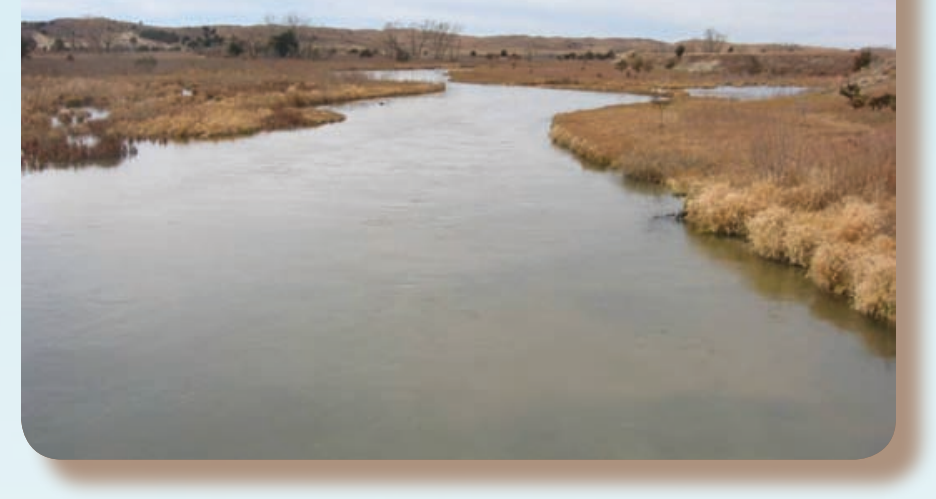

\section{Groundwater Is Vital to the High Plains Region}

The High Plains aquifer is a nationally important water resource that underlies about 174,000 square miles in parts of eight western states (fig. 1). The High Plains aquifer includes various geologic formations; however, the Ogallala Formation is the main water-bearing unit for 77 percent of the aquifer extent (McMahon and others, 2007). The aquifer serves as a primary source of drinking water for approximately 2.3 million people and also sustains more than one quarter of the Nation's agricultural production (Gurdak and others, 2009). In 2000, total water withdrawals of 17.5 billion gallons per day from the aquifer accounted for 20 percent of all groundwater withdrawn in the United States, making it the most intensively pumped aquifer in the Nation (Maupin and Barber, 2005). The aquifer supports about a $\$ 20$ billion per year agricultural industry that includes the production of 19 percent of wheat and cotton and 15 percent of corn for the United States. The dominant land uses are rangeland (56 percent) and agriculture (38 percent) (McMahon and others, 2007). About 13.1 million acres, or approximately 30 percent of agricultural land, was under irrigation in 1992 (Qi and others, 2002).

The High Plains aquifer has gained national and international attention as a highly stressed groundwater system, primarily because of extensive groundwater withdrawals causing water-level declines in many parts of the aquifer. High-volume groundwater withdrawals in some areas caused declines of as much as 234 feet from predevelopment (considered to be about 1940) to 2007, with an area-weighted average water-level decline for the entire aquifer of
14 feet (McGuire, 2009a). The continued decline in the water-table elevation, particularly in Kansas and Texas, has caused much concern about the sustainability of the aquifer and the associated agricultural production.

\section{Developing Tools for Resource Management}

The High Plains groundwater-availability team will describe the hydrogeology, quantify water-use and water-budget components (recharge, withdrawals, evapotranspiration [ET], groundwater discharge, and storage) of the aquifer, and develop tools to forecast effects of future development in the High Plains aquifer. Several issues must be addressed to more accurately assess groundwater availability in the High Plains aquifer.

\section{Water Budgets}

This project will refine water budgets for the central and southern High Plains and improve on current water budgets for the northern High Plains (fig. 1). Water budgets provide a means for evaluating the amount of and temporal trends in regional water supplies. An understanding of the High Plains aquifer water budget and underlying hydrologic processes will provide a foundation for effective water-resource and environmental planning and management. Inflow to the aquifer is primarily from recharge, which for the High Plains is estimated to be less than 1 inch per year in the west and south and 5 inches per year in the northeast (Dugan and Zelt, 2000). The largest discharge component of the water budget for the aquifer is the withdrawal of water by pumping (McGuire and others, 2003). From 1949 to 1974, groundwater

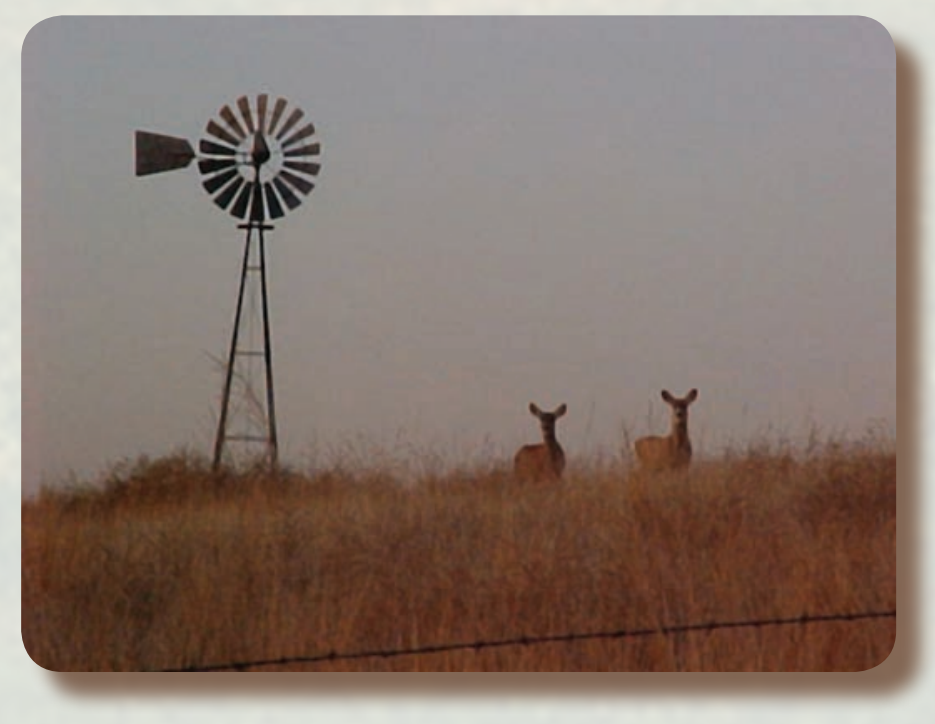


withdrawals from the aquifer for irrigation increased from 4 to 19 million acre-feet (an acre-foot is the volume of water that would cover 1 acre to a depth of 1 foot, equal to about 326,000 gallons). From 1980 to 1995 , irrigation withdrawals decreased from 18 to 16 million acre-feet and in 2005 were back up to 19 million acre-feet (McGuire, 2009b). In 2009, groundwater discharge to surface water and ET was only a small component of the water budget in the southern and central High Plains aquifer but was substantial in the northern High Plains.

Because the High Plains aquifer is an important National resource and the decline in water in storage has been substantial, the U.S. Geological Survey and its State and local partners operate a network of about 9,000 wells, by congressional directive, to monitor water levels across the aquifer. Water in storage in the High Plains aquifer in 2007 was about 2.9 billion acre-feet, which represented a decline of about 270 million acre-feet since predevelopment (McGuire, 2009).

\section{New Methods To Quantify Groundwater Irrigation Withdrawals}

A critical part of the water budget in the High Plains aquifer is the spatial distribution of groundwater irrigation withdrawals across the aquifer over time. The use of more accurate methods in determining irrigation withdrawals results in more accurate water budgets. The most accurate method for measuring the volume pumped is to meter the irrigation wells, but only a small percentage of the wells in the High Plains are metered; therefore, new methods for accurately estimating irrigation withdrawals over large areas are a priority for this study.

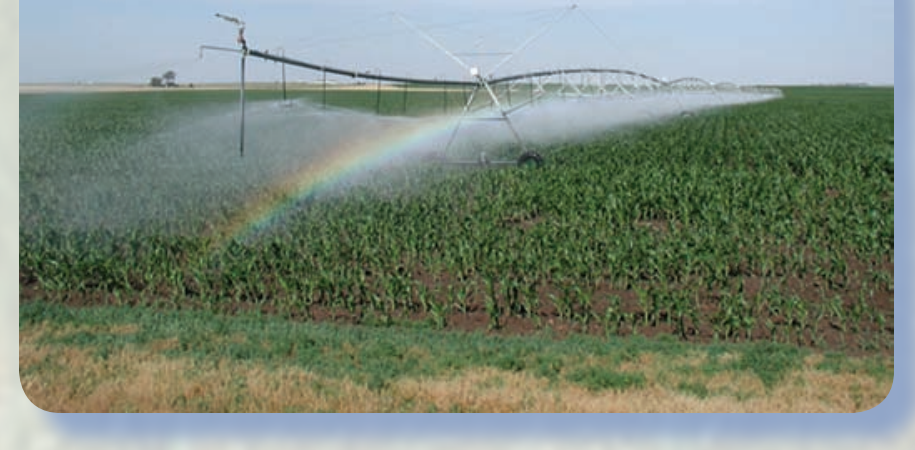

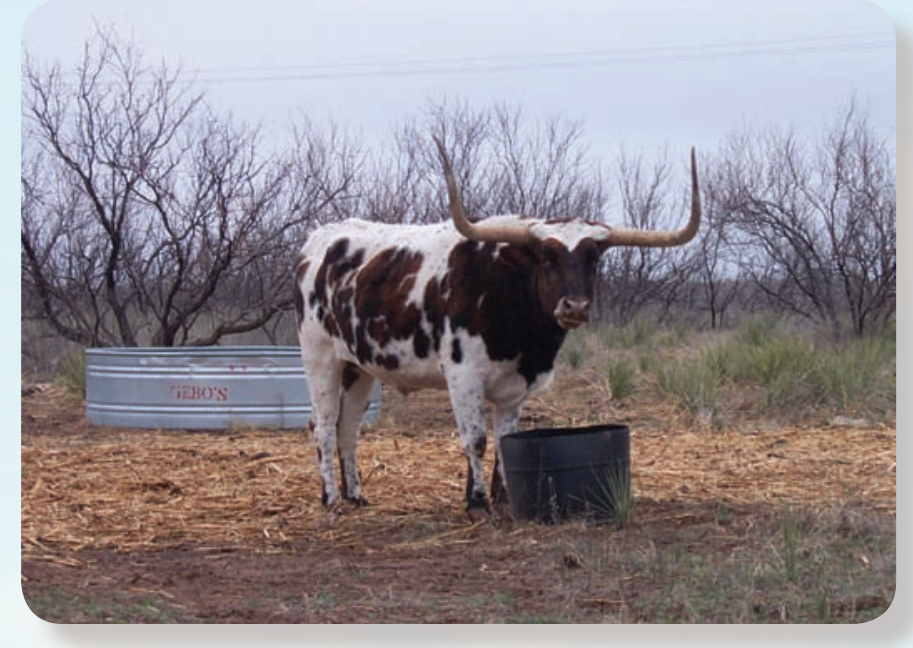

A new method for estimating irrigation withdrawals uses remotely sensed thermal satellite data and statistical land-cover modeling to determine the spatial distribution and temporal changes in ET and irrigation application of water. An approach being explored in this study involves using remotely sensed thermal data to measure ET at an aquifer scale.

Remotely sensed ET data will be combined with precipitation, runoff, and soils data to calculate irrigation withdrawals. Accurate determination of groundwater irrigation withdrawals will substantially improve the groundwater-flow model being developed for the northern High Plains.

\section{Modeling Groundwater Availability in the High Plains}

The High Plains aquifer study team plans to construct a groundwater-flow model for the northern High Plains aquifer. A groundwater model simulates the groundwater system by means of a mathematical counterpart. The groundwater-flow model of the northern High Plains will integrate the latest knowledge of the geology and hydrology of the aquifer system and will incorporate the remotely sensed ET, land cover, and withdrawal data developed as part of this study. With this model, it will be possible to study changes that occurred in the past and forecast changes that may occur within the aquifer-such as changes in water levels and the volume of water in storage-caused by pumping, changes in land use, and changes in climate. An accurate regional groundwater model will help local, State, regional, and Federal agencies assess the major inflows and outflows to the water-resource system; understand, forecast, 


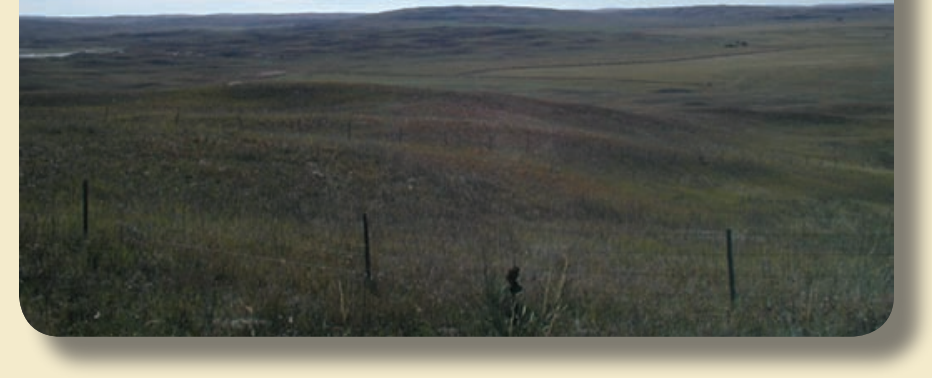

have responsibilities or interests in groundwaterresource management of the High Plains aquifer. The High Plains groundwater-availability study team is collaborating with many agencies and organizations to better understand the aquifer system. This knowledge will help provide input for developing tools to better understand the aquifer and to help make more informed decisions about the management of High Plains groundwater resources.

and manage groundwater depletion; estimate the impacts of groundwater withdrawals; and assess the effects of water-management decisions.

\section{Vital Role for Partnerships}

Multiple Federal, State, local, and nongovernment organizations, as well as Tribal organizations,

\section{References Cited}

Dugan, J.T., and Zelt, R.B., 2000, Simulation and analysis of soil-water conditions in the Great Plains and adjacent areas, central United States, 1951-80: U.S. Geological Survey Water Supply Paper 2427, 81 p.

Gurdak, J.J., McMahon, P.B., Dennehy, K.F., and Qi, S.L., 2009, Water quality in the High Plains aquifer, Colorado, Kansas, Nebraska, New Mexico, Oklahoma, South Dakota, Texas, and Wyoming, 19992004: U.S. Geological Survey Circular 1337, 63 p.

Maupin, M.A., and Barber, N.L., 2005, Estimated withdrawals from principal aquifers in the United States, 2000: U.S. Geological Survey Circular 1279, $46 \mathrm{p}$.

McGuire, V.L., 2009a, Changes in water levels and storage in the High Plains aquifer, predevelopment to 2007: U.S. Geological Survey Fact Sheet 2009-3005, $2 \mathrm{p}$.

McGuire, V.L., 2009b, Water-level changes in the High Plains aquifer, predevelopment to 2007, 2005-06, and 2006-07: U.S. Geological Survey Scientific Investigations Report 2009-5019, 18 p.

McGuire, V.L., Johnson, M.R., Schieffer, R.L., Stanton, J.S., Sebree, S.K., and Verstraeten, I.M., 2003, Water

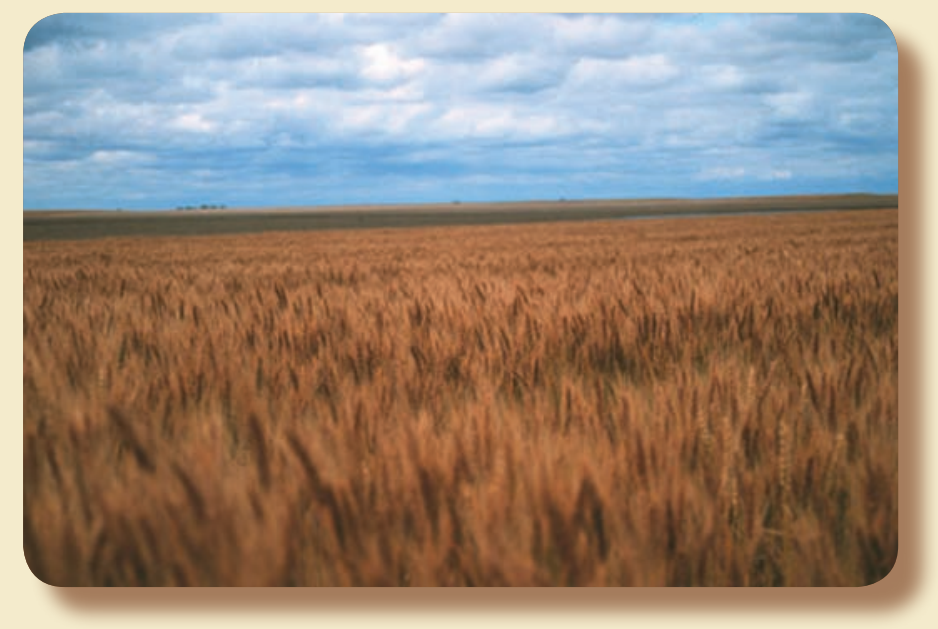

in storage and approaches to ground-water management, High Plains aquifer, 2000: U.S. Geological Survey Circular 1243, 51 p.

McMahon, P.B., Dennehy, K.F., Bruce, B.W., Gurdak, J.J., and Qi, S.L., 2007, Water-quality assessment of the High Plains aquifer, 1999-2004: U.S. Geological Survey Professional Paper 1749, 136 p.

Qi, S.L., Konduris, Alexandria, Litke, D.W., and Dupree, Jean, 2002, Classification of irrigated land using satellite imagery, the High Plains aquifer, nominal date 1992: U.S. Geological Survey WaterResources Investigations Report 02-4236, 31 p.

Reilly, T.E., Dennehy, K.F., Alley, W.M., and Cunningham, W.L., 2008, Ground-water availability in the United States: U.S. Geological Survey Circular $1323,70 \mathrm{p}$.

\section{By Sharon L. Qi and Scott Christenson}

For more information:

Visit the project Web site at http://txpub.usgs.gov/HPWA/index.html

\section{Or contact Steven M. Peterson}

U.S. Geological Survey Nebraska Water Science Center 402-328-4151

speterson@usgs.gov 